IZA DP No. 9306

The Unaccompanied Refugee Minors and the Swedish Labour Market

Aycan Çelikaksoy

Eskil Wadensjö

August 2015

Forschungsinstitut zur Zukunft der Arbeit Institute for the Study of Labor 


\title{
The Unaccompanied Refugee Minors and the Swedish Labour Market
}

\author{
Aycan Çelikaksoy \\ SOFI and SULCIS, Stockholm University \\ Eskil Wadensjö \\ SOFI and SULCIS, Stockholm University \\ and IZA
}

Discussion Paper No. 9306
August 2015

IZA

P.O. Box 7240

53072 Bonn

Germany

Phone: +49-228-3894-0

Fax: +49-228-3894-180

E-mail: iza@iza.org

\begin{abstract}
Any opinions expressed here are those of the author(s) and not those of IZA. Research published in this series may include views on policy, but the institute itself takes no institutional policy positions. The IZA research network is committed to the IZA Guiding Principles of Research Integrity.

The Institute for the Study of Labor (IZA) in Bonn is a local and virtual international research center and a place of communication between science, politics and business. IZA is an independent nonprofit organization supported by Deutsche Post Foundation. The center is associated with the University of Bonn and offers a stimulating research environment through its international network, workshops and conferences, data service, project support, research visits and doctoral program. IZA engages in (i) original and internationally competitive research in all fields of labor economics, (ii) development of policy concepts, and (iii) dissemination of research results and concepts to the interested public.
\end{abstract}

IZA Discussion Papers often represent preliminary work and are circulated to encourage discussion. Citation of such a paper should account for its provisional character. A revised version may be available directly from the author. 


\section{ABSTRACT \\ The Unaccompanied Refugee Minors and the Swedish Labour Market ${ }^{*}$}

More unaccompanied refugee children arrive to and get a residence permit in Sweden than in any other country in Europe. The number of children who arrives is increasing fast. The Swedish experiences are therefore of great interest also for other countries. In this paper we study the labour market situation in terms of employment and income for those who have arrived as unaccompanied minors and have been registered in Sweden. We compare them with those who also arrived as minors from the same countries but who have arrived together with their parents. After controlling for demographic and migration related variables we find that young adults who arrived as unaccompanied refugee children are more likely to be employed than those children who arrived accompanied from the same countries. Another result is that labour market participation is much lower for females than for males. We also compare the labour market situation of these children with that for those who were born in Sweden and are of the same age.

JEL Classification: J13, J15, J21, J31

Keywords: unaccompanied minors, refugee children, migration, employment, income

Corresponding author:

Eskil Wadensjö

Swedish Institute for Social Research

University of Stockholm

SE-106 91 Stockholm

Sweden

E-mail: Eskil.Wadensjo@sofi.su.se

\footnotetext{
* We are grateful for the many valuable comments we have received during presentations at Aarhus University, EMN in Helsinki, the $17^{\text {th }}$ Annual Conference on European Integration in Mölle, SUITS at Stockholm University, Statistics Sweden, at a conference organised by SULCIS at Stockholm University and from Christer Gerdes.
} 
Introduction

Children under the age of 18 who are outside their country of origin and came to Sweden unaccompanied by a parent or other legal guardian are defined as unaccompanied minors. Unaccompanied refugee minors come to Sweden in greater numbers than to other countries in Europe, and the number coming to Sweden greatly increases every year (Eurostat, 2015; EC, 2012; Migrationsverket, 2015). In previous reports from this project, which is funded by the European Refugee Fund, we provided an overview of the extent, composition, and outcome of this migration. ${ }^{1}$ One of many relevant issues to explore in connection with this migration is how well the unaccompanied minors succeed in establishing themselves on the labour market as they grow older. That is the focus of this paper. The study covers unaccompanied minors who arrived between 2003 and 2012. Thus, for some of them, we have information covering a ten-year period. $^{2}$

In this paper we will carry out a more detailed analysis in this area than we did in the previous papers; for example, we will investigate how the unaccompanied minors are doing compared to other minors from the same countries who arrived accompanied by a parent or other legal guardian. In addition, we will make comparisons with individuals of the same age who were born in Sweden to Swedish-born parents. In forthcoming papers we will develop the study of the unaccompanied minors' conditions in Sweden in other areas, such as education, housing, and health.

\footnotetext{
${ }^{1}$ See Çelikaksoy and Wadensjö (2015a, 2015b, 2015c).

${ }^{2}$ A previous study based on panel data is Hessle (2009). That study includes far fewer minors (68), but contains very detailed and relevant information based on interviews with the minors.
} 


\section{Finding work}

First, we will recap and slightly develop some of the main results from the previous reports with respect to the unaccompanied minors' entry into working life.

An important part of integration is to find a job and be integrated into the Swedish labour market. The difficulties for refugees to establish themselves in the labour market have been documented in numerous studies (e.g. Aldén and Hammarstedt, 2014; Ager and Strang, 2008). Access to the labour market is very important for unaccompanied minors, not least because they do not have the support of their parents when they grow up. Social workers try to facilitate the establishment in the labour market through their networks and internships (Hessle, 2009; UNHCR, 2014; Eide, 2000). Table 1 shows how big a proportion of those aged 16 and over are employed. The numbers are presented for one-year groups. We can see that very few of the teenagers have a job; most of them are students. Many more among those aged 21 and over are employed, and the proportion increases with age when we compare different age groups with each other. This age group includes quite a few students, as well (see our first report). Here it is important to remember that the individuals included in the study have been in Sweden for different periods of time and that the observations are taken from different calendar years (2003-2012).

We can see that there are major differences between men and women. In each age group, there is a much higher proportion of employed men than employed women. This difference is much greater than what we find among their Swedish-born counterparts. It is important to examine this pattern more closely. One explanation might be that this difference reflects differences in women and men's participation in the labour market in their home countries. See Neuman (2015).

The table also presents the corresponding numbers for individuals from the same countries who did not come as unaccompanied minors, as well as for individuals of the same age who were born in Sweden to Swedish-born parents. Out of the individuals who came from the same countries, but not as unaccompanied minors, we have included those who were entered into the population register before or during the year they turned 19 years old. Our reason for choosing 19 instead of 17 or 18 is that it takes time for an asylum application to be processed, and we wanted our groups to be as comparable as possible. If we did not have an age restriction at all with reference to their age during the year of registration, the results would include many individuals who arrived as young adults and thus probably did not go to school in Sweden. 
Those who came as unaccompanied minors were generally much older when they arrived, often 16 or 17 years old, compared to those who came with their parents from the same countries. The latter group of minors have thus been in Sweden longer, have generally undergone several years of education in Sweden, and have had more long-term contact with Swedish society. In the continued analysis, we will take into account differences in the length of stay in Sweden.

The countries and groups of countries we have included in this paper (unaccompanied minors and a comparison group from the same countries) are Afghanistan, Iraq, Iran, Other Middle Eastern countries, Other Asian countries, Somalia, Syria, Eritrea, Morocco, Algeria, Ethiopia, Gambia, Uganda, Other North African countries, Other African countries, Albania, Turkey, and Other European countries (non-EU/EEA countries).

Table 1. Proportion (\%) of employed unaccompanied minors, other individuals from the same countries, and Swedish-born individuals with Swedish-born parents, aged 16-27.

\begin{tabular}{|l|c|c|c|c|c|c|}
\hline \multirow{2}{*}{ Age } & \multicolumn{2}{|c|}{$\begin{array}{c}\text { Unaccompanied } \\
\text { minors }\end{array}$} & $\begin{array}{c}\text { Came from the same } \\
\text { countries, but not as } \\
\text { unaccompanied } \\
\text { minors }\end{array}$ & $\begin{array}{c}\text { Born in Sweden to Swedish- } \\
\text { born parents }\end{array}$ \\
\cline { 2 - 8 } & Women & Men & Women & Men & Women & Men \\
\hline 16 & 0 & 0 & 1 & 1 & 2 & 2 \\
\hline 17 & 0 & 1 & 4 & 3 & 8 & 5 \\
\hline 18 & 2 & 5 & 11 & 9 & 22 & 17 \\
\hline 19 & 8 & 12 & 25 & 24 & 54 & 49 \\
\hline 20 & 11 & 19 & 26 & 28 & 58 & 54 \\
\hline 21 & 22 & 33 & 34 & 38 & 61 & 60 \\
\hline 22 & 29 & 45 & 40 & 46 & 62 & 65 \\
\hline 23 & 39 & 53 & 45 & 52 & 64 & 68 \\
\hline 24 & 46 & 60 & 51 & 57 & 69 & 71 \\
\hline 25 & 52 & 62 & 53 & 58 & 71 & 72 \\
\hline 26 & 47 & 64 & 57 & 62 & 75 & 78 \\
\hline 27 & 45 & 65 & 61 & 65 & 79 & 82 \\
\hline
\end{tabular}

Note: Proportion with employment during a reference week in November each year, according to register-based employment statistics from Statistics Sweden. For the group born in Sweden to Swedish-born parents, the numbers represent a 10 per cent sample from 2012.

In the slightly older groups, the proportion of employed men is about the same for those who came as unaccompanied minors and others from the same countries; however, there are differences when it comes to women. We have not accounted for the length of stay (the groups 
have arrived at different ages), something that we will account for in the continued analysis along with other differences between the two groups. The results will be presented in a later section of this paper.

An important question is what kind of jobs the unaccompanied minors have. Here we will present information about occupations based on a relatively rough division into the ten fields of work that the official statistics are divided into. ${ }^{3}$ See Table 2.

It is clear from the table that the occupational distribution differs greatly between men and women, even when divided only into the ten occupational areas. It reflects the fact that the Swedish labour market is segregated by occupation. A very high proportion of women have service, care, and sales jobs. At the next level of the occupational data, more than 90 per cent of the women work in health and social care. Many of the men work in service professions, but many also have traditional blue-collar jobs, such as unskilled labour in construction, manufacturing, machine operator work, transport work, etc., as well as work that does not require special training. Few women or men have jobs that require higher education. It is important to remember that this is a young group, that few of them have undergone higher education, and that few of them have undergone education in Sweden for more than a few years.

It is particularly common in the younger age groups to work in unknown fields. There are several explanations for this. Wage data are not collected for those under the age of 18 (some of those who turned 18 during the year of study were 17 when the information was submitted to SCB). Furthermore, SCB does not collect wage data for temporary workers or substitutes if they did not work in September (this also applies to others who did not work during this month). Many young people have that type of job. Occupational data is also missing for students, interns, and apprentices, as well as for employees working under piece-work contracts or on commission. In addition, the coverage is not complete with regard to work places. The wage structure statistics for the public sector have close to 100 per cent coverage. This is also true for private-sector companies with many employees, while small businesses, where a large proportion of young

\footnotetext{
${ }^{3}$ The Swedish classification of occupations, SSYK3, is based on an international classification of occupations, ISCO88. It is hierarchically structured with four levels: one-digit code, Occupational area (10); two-digit code, Main group (27); three-digit code, Occupational group (113); and four-digit code, Subgroup (355).
} 
people are likely to work, are subject to a sample survey. ${ }^{4}$ However, SCB attempts to complement the occupational data with other surveys.

When we examine the occupational distribution at the two- and three-digit levels more closely, we find that the men are distributed across several occupational groups within the areas in which they are numerous. By far the most common occupation is restaurant worker, followed by cleaner (second) and driver (third). Among women, the most common occupational group is, as mentioned previously, health and social care workers.

${ }^{4}$ Thanks to Susanne Gullberg Brännström at Statistics Sweden for explanatory comments. 
Table 2. Percentage distribution across different occupations for those aged 18 and over with employment.

a) Men

\begin{tabular}{|l|l|l|l|l|l|l|l|l|l|l|l|}
\hline \multicolumn{2}{|c|}{ Field of work } & \multicolumn{9}{|c|}{ Age } \\
\cline { 2 - 13 } & 18 & 19 & 20 & 21 & 22 & 23 & 24 & 25 & 26 & 27 \\
\hline 1 & Management & 0 & 0 & 0 & 0 & 1 & 0 & 1 & 1 & 0 & 0 \\
\hline 2 & $\begin{array}{l}\text { Work that requires specialist } \\
\text { knowledge }\end{array}$ & 0 & 0 & 0 & 1 & 1 & 1 & 1 & 1 & 2 & 4 \\
\hline 3 & Work that requires higher education & 0 & 1 & 1 & 1 & 3 & 3 & 4 & 4 & 6 & 4 \\
\hline 4 & Office and customer service work & 1 & 2 & 4 & 4 & 7 & 8 & 11 & 9 & 14 & 7 \\
\hline 5 & Service, care, and sales work & 11 & 12 & 20 & 20 & 20 & 23 & 22 & 19 & 17 & 24 \\
\hline 6 & $\begin{array}{l}\text { Work in farming, gardening, } \\
\text { forestry, and fishing }\end{array}$ & 0 & 0 & 0 & 0 & 0 & 0 & 0 & 0 & 0 & 0 \\
\hline 7 & $\begin{array}{l}\text { Unskilled labour in construction or } \\
\text { manufacturing }\end{array}$ & 3 & 4 & 5 & 6 & 8 & 7 & 10 & 15 & 17 & 22 \\
\hline 8 & $\begin{array}{l}\text { Machine operator work, transport } \\
\text { work, etc. }\end{array}$ & 1 & 4 & 6 & 8 & 9 & 12 & 17 & 22 & 20 & 17 \\
\hline 9 & $\begin{array}{l}\text { Work without requirements for } \\
\text { special training }\end{array}$ & 23 & 24 & 26 & 25 & 24 & 20 & 20 & 14 & 15 & 15 \\
\hline 0 & Military work & 0 & 0 & 0 & 0 & 0 & 0 & 0 & 0 & 0 & 0 \\
\hline & Unknown & 62 & 53 & 39 & 36 & 28 & 26 & 16 & 14 & 11 & 7 \\
\hline
\end{tabular}

Women

\begin{tabular}{|l|l|l|l|l|l|l|l|l|l|l|l|l|}
\hline \multicolumn{2}{|c|}{ Field of work } & \multicolumn{9}{|c|}{ Age } \\
\cline { 2 - 13 } & 18 & 19 & 20 & 21 & 22 & 23 & 24 & 25 & 26 & 27 \\
\hline 1 & Management & 0 & 0 & 0 & 0 & 0 & 0 & 0 & 0 & 0 & 0 \\
\hline 2 & $\begin{array}{l}\text { Work that requires specialist } \\
\text { knowledge }\end{array}$ & 0 & 0 & 2 & 0 & 1 & 3 & 5 & 2 & 4 & 0 \\
\hline 3 & Work that requires higher education & 1 & 2 & 0 & 0 & 1 & 1 & 2 & 6 & 4 & 0 \\
\hline 4 & Office and customer service work & 0 & 0 & 0 & 0 & 0 & 0 & 0 & 0 & 0 & 0 \\
\hline 5 & Service, care, and sales work & 25 & 39 & 69 & 71 & 72 & 68 & 73 & 75 & 74 & 100 \\
\hline 6 & $\begin{array}{l}\text { Work in farming, gardening, } \\
\text { forestry, and fishing }\end{array}$ & 0 & 0 & 0 & 0 & 0 & 0 & 0 & 0 & 0 & 0 \\
\hline 7 & $\begin{array}{l}\text { Unskilled labour in construction or } \\
\text { manufacturing }\end{array}$ & 0 & 0 & 0 & 1 & 1 & 0 & 0 & 0 & 0 & 0 \\
\hline 8 & $\begin{array}{l}\text { Machine operator work, transport } \\
\text { work, etc. }\end{array}$ & 0 & 0 & 2 & 1 & 0 & 1 & 2 & 2 & 0 & 0 \\
\hline 9 & $\begin{array}{l}\text { Work without requirements for } \\
\text { special training }\end{array}$ & 0 & 14 & 8 & 7 & 9 & 8 & 6 & 2 & 7 & 0 \\
\hline 0 & Military work & 0 & 0 & 0 & 0 & 0 & 0 & 0 & 0 & 0 & 0 \\
\hline & Unknown & 75 & 46 & 20 & 21 & 15 & 20 & 13 & 13 & 11 & 0 \\
\hline
\end{tabular}

2. What factors affect whether an unaccompanied minor has a job?

In Table 1 we provided an overview of the employment rate among unaccompanied minors of different ages in Sweden. We will now examine this employment rate a little closer. In Table 1 we only divided the groups by age and sex, but there may be other significant factors as well. We have taken this into account in the calculations presented in Table 3. The table shows the 
marginal effects from probit estimations. We have also made estimations using other methods (OLS, logit). The results are qualitatively similar; they suggest that the same factors are important for the likelihood of having a job regardless of which estimation method we use. The table shows that women are less often employed than men, based on the characteristics we are able to account for. In addition, we can see that the proportion of employed individuals not surprisingly increases with age (the value for the 27-30 age group is not significantly higher than for the 16-18 group among women, but very few women in the group are of that age, so the estimate for that age group is based on few observations; even the number of 25-26-year-olds is low in this population).

The chances of somebody being employed can be assumed to depend on the length of their stay in Sweden; the longer somebody has been in Sweden given their age, the more likely they are to be employed. Those who have been in Sweden for a longer period of time have generally gone to school in Sweden longer and probably learnt better Swedish. We have taken into account the number of days that an individual has been registered in Sweden; unsurprisingly, the results show that those who have been registered (in the population register) longer, given their age and other characteristics, are more likely to be employed. In addition, we have checked whether the observation refers to the first year that the person was registered in Sweden. Those who were registered the same year that the observation was made have generally had less time to seek employment.

We also investigate the importance of education, which is done by taking into account whether the person is studying and thus less likely to work during the survey year, but also the importance of an individual's highest completed education (in Sweden or abroad). Many studies of the Swedish labour market show that the likelihood of a person being employed increases with the level of education. The calculations show that those who have completed upper secondary school are more often employed than those with a shorter education. Those undergoing education are, as excepted, less often employed (although many people of course combine work and education). 
Table 3. Employment rate among unaccompanied minors. Probit estimations, marginal effects.

\begin{tabular}{|c|c|c|c|}
\hline Variables & All & Male & Female \\
\hline \multirow[t]{2}{*}{ Female } & -0.033 & & \\
\hline & $(0.003) * *$ & & \\
\hline Age 16-18 & \multicolumn{2}{|c|}{ Reference group } & \\
\hline \multirow[t]{2}{*}{\begin{tabular}{|l|} 
Age $19-21$ \\
\end{tabular}} & 0.074 & 0.071 & 0.091 \\
\hline & $(0.006)^{* *}$ & $(0.007) * *$ & $(0.015)^{* *}$ \\
\hline \multirow[t]{2}{*}{ Age 22-24 } & 0.147 & 0.144 & 0.166 \\
\hline & $(0.016)^{* *}$ & $(0.018) * *$ & $(0.035)^{* *}$ \\
\hline \multirow[t]{2}{*}{ Age 25-26 } & 0.133 & 0.119 & 0.169 \\
\hline & $(0.025)^{* *}$ & $(0.029) * *$ & $(0.055)^{* *}$ \\
\hline \multirow[t]{2}{*}{ Age 27-30 } & 0.078 & 0.079 & 0.058 \\
\hline & $(0.032)^{*}$ & $(0.038)^{*}$ & (0.054) \\
\hline \multirow[t]{2}{*}{ Under education } & -0.053 & -0.068 & -0.015 \\
\hline & $(0.005) * *$ & $(0.006) * *$ & $(0.006)^{* *}$ \\
\hline Compulsory edu $<9$ yrs & \multicolumn{2}{|c|}{ Reference group } & \\
\hline \multirow[t]{2}{*}{ Compulsory edu (9 yrs) } & -0.002 & 0.001 & -0.003 \\
\hline & $(0.004)$ & (0.005) & $(0.007)$ \\
\hline \multirow[t]{2}{*}{ High school } & 0.051 & 0.047 & 0.058 \\
\hline & $(0.007)^{* *}$ & $(0.009)^{* *}$ & $(0.016)^{* *}$ \\
\hline \multirow[t]{2}{*}{ Short tertiary edu } & 0.029 & 0.053 & 0.001 \\
\hline & $(0.016)$ & $(0.023)^{*}$ & $(0.016)$ \\
\hline \multirow[t]{2}{*}{ Long tertiary edu } & 0.039 & 0.032 & 0.043 \\
\hline & $(0.021)$ & $(0.025)$ & $(0.033)$ \\
\hline \multirow{2}{*}{ Missing edu } & -0.008 & -0.005 & -0.005 \\
\hline & (0.004) & (0.005) & (0.008) \\
\hline \multirow[t]{2}{*}{ Days registered in Sweden/100 } & 0.004 & 0.004 & 0.002 \\
\hline & $(0.000) * *$ & $(0.000) * *$ & $(0.000)^{* *}$ \\
\hline \multirow[t]{2}{*}{ First year } & -0.055 & -0.064 & -0.015 \\
\hline & $(0.004)^{* *}$ & $(0.005) * *$ & $(0.012)$ \\
\hline \multirow[t]{2}{*}{ Parents registered in Sweden } & -0.016 & -0.010 & -0.023 \\
\hline & $(0.004)^{* *}$ & $(0.005)^{*}$ & $(0.005)^{* *}$ \\
\hline \multirow[t]{2}{*}{ Single } & -0.010 & -0.023 & -0.000 \\
\hline & $(0.005)^{*}$ & $(0.007)^{* *}$ & (0.005) \\
\hline \multirow[t]{2}{*}{ Moving across counties } & -0.005 & -0.010 & 0.007 \\
\hline & $(0.003)$ & $(0.004)^{*}$ & $(0.005)$ \\
\hline Stockholm & \multicolumn{2}{|c|}{ Reference group } & \\
\hline Skåne & -0.043 & -0.048 & -0.029 \\
\hline & $(0.003) * *$ & $(0.003)^{* *}$ & $(0.004)^{* *}$ \\
\hline Västra Götaland & -0.027 & -0.031 & -0.016 \\
\hline & $(0.003) * *$ & $(0.004) * *$ & $(0.005)^{* *}$ \\
\hline Other counties & -0.043 & -0.055 & -0.014 \\
\hline & $(0.004)^{* *}$ & $(0.004)^{* *}$ & $(0.005)^{* *}$ \\
\hline Afghanistan & Reference & & \\
\hline Irak & -0.003 & -0.002 & -0.020 \\
\hline & $(0.004)$ & $(0.004)$ & $(0.008)^{*}$ \\
\hline Somalia & -0.027 & -0.029 & -0.013 \\
\hline & $(0.003) * *$ & $(0.004)^{* *}$ & $(0.011)$ \\
\hline Other countries in the M.E. & -0.006 & -0.010 & 0.009 \\
\hline & $(0.007)$ & $(0.008)$ & $(0.017)$ \\
\hline Other countries in Africa & -0.002 & -0.028 & 0.021 \\
\hline & (0.005) & $(0.005)^{* *}$ & (0.015) \\
\hline Europé & -0.029 & -0.018 & -0.024 \\
\hline & $(0.006) * *$ & $(0.011)$ & $(0.007)^{* *}$ \\
\hline Other countries in Asia & 0.004 & -0.009 & 0.028 \\
\hline & $(0.010)$ & $(0.011)$ & $(0.026)$ \\
\hline Number of obs. & 24,070 & 18,749 & 5,321 \\
\hline
\end{tabular}

* indicates significance at the 5-\% level, and ** at the 1-\% level. 
The labour market situation is markedly different in different parts of the country. Therefore, we investigate the significance of this for the unaccompanied minors by including the county of residence in the estimations. The results show that the employment rate among residents of Stockholm County is higher than among residents of other counties. The differences are greater among boys than among girls. In this calculation we have divided the counties into Stockholm (control group), Skåne, Västra Götaland, and Other counties (combined). ${ }^{5}$ Here we have used information about the county of residence from the year that the employment situation was observed. We have also included a variable for moving to a different county, which, perhaps surprisingly, shows a weak negative effect. It is not likely that moving to a different county leads to a negative result, but rather that the employment rate among those who move is low both before and after moving. If we instead include moving to Stockholm County as a variable, we can see a negative effect for boys and a positive effect for girls.

More surprising is that the unaccompanied minors whose parents were also registered, either before, at the same time, or after the child ${ }^{6}$, are less often employed. It is important to note that this pattern is most evident among girls. This may have several possible explanations: 1) Those who are not reunited with their parents can, in various respects, be a select group of more independent persons, 2) They can be helped by foster families to integrate into Swedish society, 3) Unaccompanied minors who are reunited with their parent may be given responsibilities within the family household, and 4) Those who do not have their parents in Sweden may be under more financial pressure and have to work in order to earn a living, possibly in addition to helping to support family members in their home country. Something that suggests that this might be the case is that, when we make similar estimations relating to participation in education, the proportion is higher among those who have been reunited with their parents. On the other hand, those who have been reunited are more commonly included in the NEET group (not in employment, education, or training).

Finally, we want to compare how unaccompanied minors from different countries are doing can we find any differences? In the comparison of minors from different countries we have

\footnotetext{
${ }^{5}$ We have also made calculations where each county is included as its own variable. The results were that no county has a higher employment rate than Stockholm County, given other variables.

${ }^{6}$ See text box.
} 
chosen to use the largest group, those from Afghanistan, as a comparison group. It turns out that minors from this country are just as likely to be employed, or even more so, as those from other countries. The employment rate is lower among boys from Somalia and Other African countries, as well as among girls from Iraq and Europe ${ }^{7}$.

Some of the results might be due to the fact that they, in practice, only apply to the largest group or that there is a covariance between the explanatory variables and the country of birth. Therefore, we have made separate calculations for the four countries/groups of countries from which most individuals originate (Afghanistan, Iraq, Somalia, and Other African countries). We present the results of these calculations in four appendix tables. We find that the results are essentially the same. The same variables are generally significant (though not always, which is likely due to the fact that there are fewer observations in each estimate), and the coefficient estimates are very similar when we compare the estimates for each country/group of countries.

\section{Reunion with their parents}

Unaccompanied minors do not arrive at the same time as their parents, but they may, for example, be registered at the same time as their parents who arrived later. Here we would like to emphasise that unaccompanied minors may arrive together with other relatives or be reunited with relatives already living in Sweden, or that other relatives will arrive later. See Hessle (2009) for examples. Out of the unaccompanied minors included in this study, 27 per cent had reunited with at least one parent in Sweden: 21 per cent of the boys and 44 per cent of the girls. Most of them had been reunited with one parent. The proportion of unaccompanied minors reunited with at least one parent varies by country of birth; 13 per cent of those from Afghanistan, 31 per cent of those from Somalia, 28 per cent of those from Iraq, and 32 per cent of those from Other African countries had been reunited with their parents.

\footnotetext{
${ }^{7}$ Europe refers to countries outside the EU/EEA. The data primarily include unaccompanied minors from Albania, Kosovo, and Serbia.
} 
3. How are unaccompanied refugee minors doing compared to other minors from the same countries?

The next question is how unaccompanied minors are doing compared to minors from the same countries who arrived together with a parent or other legal guardian. To investigate this we make the same calculations as before, but including children from both groups. We will have the same set of variables, but with one additional variable - the variable that the minor arrived unaccompanied. See Table 4.

Without considering any other variables, unaccompanied minors are less likely to be employed. If we include sex, age, and education, this difference disappears. If we also factor in length of stay in Sweden, the result is the opposite, and if we include additional control variables, the main result is that unaccompanied minors are more likely to be employed than those who did not arrive unaccompanied. The difference is not negligible. The coefficient estimate for the entire population, both men and women, is about 6 per cent. This difference can be attributed to the men. If we separate women and men, we find a significant difference for men, but not for women. This raises the question of what causes this significant difference. For example, is it because the groups were selected in different ways, or because they were received differently? We have also made similar estimations regarding participation in education, ${ }^{8}$ where we find that unaccompanied minors are more often undergoing education when we make calculations for men and women together, but not when we make calculations for men and women separately (the effect goes in the same direction, but the values are not significant). When we make the same calculations regarding the NEET group we find that, given other characteristics, a lower proportion of unaccompanied minors belong to this group. This applies to both men and women. Other variables provide results similar to the estimation that was limited to unaccompanied minors when it comes to signs and significance; however, the effects of different variables are more often significant (many more observations) and generally much larger. This is the case with, for example, the variables corresponding to other counties than Stockholm.

\footnotetext{
${ }^{8}$ The calculations regarding participation in education and the NEET group are not presented here, but are available from the authors.
} 
Table 4. Employment among unaccompanied and other minors from the same countries. Probit estimations.

\begin{tabular}{|c|c|c|c|c|c|c|}
\hline Variables & All (1) & All (2) & All (3) & All (4) & Male & Female \\
\hline \multirow[t]{2}{*}{ Unaccompanied } & -0.277 & 0.000 & 0.033 & 0.057 & 0.039 & 0.007 \\
\hline & $(0.002)^{* *}$ & $(0.005)$ & $(0.005) * *$ & $(0.005)^{* *}$ & $(0.006)^{* *}$ & $(0.010)$ \\
\hline \multirow[t]{2}{*}{ Female } & & -0.033 & -0.033 & -0.042 & & \\
\hline & & $(0.001)^{* *}$ & $(0.001)^{* *}$ & $(0.001)^{* *}$ & & \\
\hline Age 16-18 & \multicolumn{2}{|c|}{ Reference group } & & & & \\
\hline \multirow[t]{2}{*}{ Age 19-21 } & & 0.211 & 0.207 & 0.212 & 0.232 & 0.194 \\
\hline & & $(0.002)^{* *}$ & $(0.002)^{* *}$ & $(0.002)^{* *}$ & $(0.003)^{* *}$ & $(0.003)^{* *}$ \\
\hline \multirow[t]{2}{*}{ Age 22-24 } & & 0.319 & 0.304 & 0.307 & 0.351 & 0.262 \\
\hline & & $(0.002) * *$ & $(0.002) * *$ & $(0.002)^{* *}$ & $(0.003) * *$ & $(0.004) * *$ \\
\hline \multirow{2}{*}{ Age 25-26 } & & 0.361 & 0.333 & 0.331 & 0.373 & 0.286 \\
\hline & & $(0.002)^{* *}$ & $(0.003)^{* *}$ & $(0.003)^{* *}$ & $(0.004)^{* *}$ & $(0.004)^{* *}$ \\
\hline \multirow[t]{2}{*}{ Age $27-30$} & & 0.408 & 0.366 & 0.359 & 0.396 & 0.314 \\
\hline & & $(0.002)^{* *}$ & $(0.002)^{* *}$ & $(0.003)^{* *}$ & $(0.004)^{* *}$ & $(0.004)^{* *}$ \\
\hline \multirow[t]{2}{*}{\begin{tabular}{|l|} 
Under education \\
\end{tabular}} & & -0.242 & -0.237 & -0.231 & -0.253 & -0.207 \\
\hline & & $(0.001)^{* *}$ & $(0.001)^{* *}$ & $(0.001)^{* *}$ & $(0.002)^{* *}$ & $(0.002)^{* *}$ \\
\hline \multirow[t]{2}{*}{ Compulsory edu (9 år) } & & 0.115 & 0.077 & 0.070 & 0.056 & 0.095 \\
\hline & & $(0.003)^{* *}$ & $(0.003) * *$ & $(0.003) * *$ & $(0.004)^{* *}$ & $(0.004)^{* *}$ \\
\hline \multirow[t]{2}{*}{ High School } & & 0.300 & 0.254 & 0.242 & 0.230 & 0.269 \\
\hline & & $(0.003)^{* *}$ & $(0.003)^{* *}$ & $(0.003)^{* *}$ & $(0.004)^{* *}$ & $(0.004)^{* *}$ \\
\hline \multirow[t]{2}{*}{ Short tertiary edu } & & 0.249 & 0.192 & 0.174 & 0.169 & 0.195 \\
\hline & & $(0.003)^{* *}$ & $(0.004)^{* *}$ & $(0.004)^{* *}$ & $(0.005)^{* *}$ & $(0.005)^{* *}$ \\
\hline \multirow{2}{*}{\begin{tabular}{|l} 
Long tertiary edu \\
\end{tabular}} & & 0.387 & 0.332 & 0.312 & 0.282 & 0.351 \\
\hline & & $(0.003)^{* *}$ & $(0.003)^{* *}$ & $(0.003) * *$ & $(0.005)^{* *}$ & $(0.005)^{* *}$ \\
\hline \multirow[t]{2}{*}{ Missing edu } & & -0.103 & -0.105 & -0.101 & -0.077 & -0.114 \\
\hline & & $(0.003)^{* *}$ & $(0.003)^{* *}$ & $(0.003)^{* *}$ & $(0.004)^{* *}$ & $(0.004)^{* *}$ \\
\hline \multirow[t]{2}{*}{ Days registered in Sweden/100 } & & & 0.002 & 0.002 & 0.001 & 0.003 \\
\hline & & & $(0.000)^{* *}$ & $(0.000)^{* *}$ & $(0.000)^{* *}$ & $(0.000)^{* *}$ \\
\hline \multirow[t]{2}{*}{ First year } & & & & -0.028 & -0.039 & -0.017 \\
\hline & & & & $(0.002) * *$ & $(0.002)^{* *}$ & $(0.002)^{* *}$ \\
\hline \multirow[t]{2}{*}{ Single } & & & & -0.041 & -0.132 & -0.008 \\
\hline & & & & $(0.001)^{* *}$ & $(0.002)^{* *}$ & $(0.002)^{* *}$ \\
\hline \multirow[t]{2}{*}{ Moving across counties } & & & & -0.012 & -0.022 & -0.006 \\
\hline & & & & $(0.001)^{* *}$ & $(0.002)^{* *}$ & $(0.002) * *$ \\
\hline Stockholm & \multicolumn{2}{|c|}{ Reference group } & & & & \\
\hline Skåne & & & & -0.130 & -0.130 & -0.130 \\
\hline & & & & $(0.001)^{* *}$ & $(0.002)^{* *}$ & $(0.002)^{* *}$ \\
\hline West Götaland & & & & -0.062 & -0.058 & -0.066 \\
\hline & & & & $(0.001)^{* *}$ & $(0.002)^{* *}$ & $(0.002)^{* *}$ \\
\hline Other counties & & & & -0.083 & -0.089 & -0.078 \\
\hline & & & & $(0.001)^{* *}$ & $(0.002)^{* *}$ & $(0.002)^{* *}$ \\
\hline Afghanistan & Reference gr & & & & & \\
\hline Irak & & & & -0.041 & -0.033 & -0.038 \\
\hline & & & & $(0.003) * *$ & $(0.004)^{* *}$ & $(0.005)^{* *}$ \\
\hline Somalia & & & & -0.144 & -0.199 & -0.064 \\
\hline & & & & $(0.003)^{* *}$ & $(0.003)^{* *}$ & $(0.005)^{* *}$ \\
\hline Other countries in the M.E. & & & & -0.062 & -0.068 & -0.031 \\
\hline & & & & $(0.003) * *$ & $(0.004)^{* *}$ & $(0.005)^{* *}$ \\
\hline Other countries in Africa & & & & -0.055 & -0.106 & 0.021 \\
\hline & & & & $(0.003) * *$ & $(0.004)^{* *}$ & $(0.006)^{* *}$ \\
\hline Europé & & & & 0.054 & 0.027 & 0.102 \\
\hline & & & & $(0.003)^{* *}$ & $(0.004)^{* *}$ & $(0.006)^{* *}$ \\
\hline Other countries in Asia & & & & -0.005 & -0.016 & 0.024 \\
\hline & & & & $(0.003)$ & $(0.004)^{* *}$ & $(0.005)^{* *}$ \\
\hline Number of obs. & $1,072,348$ & $1,072,348$ & $1,072,348$ & $1,072,348$ & 542,826 & 529,522 \\
\hline
\end{tabular}


4. How are unaccompanied refugee minors and other children from the same countries doing compared to children with a Swedish background?

We have also compared the situation of individuals who arrived as unaccompanied minors or together with a parent or other legal guardian from the same countries to that of individuals of the same age who were born in Sweden to Swedish-born parents. See Table 5.

With a few exceptions, the same variables are included in these calculations as in the previous ones. Notable exceptions are that the country of birth and the number of days registered in Sweden are not included for the two groups that have come to Sweden. When comparing these two groups, this may reduce or eliminate the difference between them found in the preceding section (on average, the children who did not arrive unaccompanied came at a younger age).

We find that the employment rate among those with a Swedish background is much higher than in the two groups of refugee minors. The difference is between 15 and 20 per cent when taking age and other variables into account. Once again we can see that the employment rate among the unaccompanied minors is slightly higher than in the other group when taking into account other variables such as age, length of stay, education, and county of residence - and this result is driven by males.

With many more observations, all coefficient estimates become clearly significant. 
Table 5. Employment among minors - unaccompanied, others from the same countries, Swedish background.

\begin{tabular}{|c|c|c|c|c|c|c|}
\hline Variables & All (1) & All (2) & Male (1) & Male (2) & Female (1) & Female (2) \\
\hline Child+parents born in Sweden & \multicolumn{2}{|c|}{ Reference Category } & & & & \\
\hline \multirow[t]{2}{*}{\begin{tabular}{|l|} 
Unaccompanied \\
\end{tabular}} & -0.359 & -0.102 & -0.410 & -0.091 & -0.412 & -0.180 \\
\hline & $(0.002)^{* *}$ & $(0.009)^{* *}$ & $(0.004)^{* *}$ & $(0.010)^{* *}$ & $(0.006)^{* *}$ & $(0.017)^{* *}$ \\
\hline \multirow[t]{2}{*}{ Accompanied } & -0.308 & -0.153 & -0.164 & -0.153 & -0.188 & -0.154 \\
\hline & $(0.002)^{* *}$ & $(0.002)^{* *}$ & $(0.003)^{* *}$ & $(0.003)^{* *}$ & $(0.003)^{* *}$ & $(0.004)^{* *}$ \\
\hline \multirow[t]{2}{*}{ Female } & & -0.013 & & & & \\
\hline & & $(0.002)^{* *}$ & & & & \\
\hline Age $16-18$ & \multicolumn{2}{|c|}{ Reference Category } & & & & \\
\hline \multirow[t]{2}{*}{ Age 19-21 } & & 0.178 & & 0.191 & & 0.158 \\
\hline & & $(0.005)^{* *}$ & & $(0.007)^{* *}$ & & $(0.007) * *$ \\
\hline \multirow[t]{2}{*}{ Age 22-24 } & & 0.276 & & 0.310 & & 0.229 \\
\hline & & $(0.005) * *$ & & $(0.007) * *$ & & $(0.007) * *$ \\
\hline \multirow[t]{2}{*}{\begin{tabular}{|l|} 
Age 25-26 \\
\end{tabular}} & & 0.318 & & 0.349 & & 0.275 \\
\hline & & $(0.005)^{* *}$ & & $(0.007)^{* *}$ & & $(0.008)^{* *}$ \\
\hline \multirow{2}{*}{\begin{tabular}{|l|} 
Age $27-30$ \\
\end{tabular}} & & 0.383 & & 0.412 & & 0.337 \\
\hline & & $(0.005)^{* *}$ & & $(0.006)^{* *}$ & & $(0.007)^{* *}$ \\
\hline \multirow[t]{2}{*}{\begin{tabular}{|l|} 
Under education \\
\end{tabular}} & & -0.323 & & -0.350 & & -0.295 \\
\hline & & $(0.002)^{* *}$ & & $(0.003)^{* *}$ & & $(0.004)^{* *}$ \\
\hline \multirow[t]{2}{*}{ Compulsory edu (9 år) } & & 0.091 & & 0.055 & & 0.147 \\
\hline & & $(0.008)^{* *}$ & & $(0.011)^{* *}$ & & $(0.013)^{* *}$ \\
\hline \multirow[t]{2}{*}{ High School } & & 0.336 & & 0.294 & & 0.406 \\
\hline & & $(0.007)^{* *}$ & & $(0.010)^{* *}$ & & $(0.011)^{* *}$ \\
\hline \multirow[t]{2}{*}{\begin{tabular}{|l} 
Short tertiary edu \\
\end{tabular}} & & 0.250 & & 0.195 & & 0.326 \\
\hline & & $(0.008)^{* *}$ & & $(0.011)^{* *}$ & & $(0.011)^{* *}$ \\
\hline \multirow[t]{2}{*}{ Long tertiary edu } & & 0.372 & & 0.300 & & 0.460 \\
\hline & & $(0.006)^{* *}$ & & $(0.010)^{* *}$ & & $(0.009)^{* *}$ \\
\hline \multirow[t]{2}{*}{ Missing edu } & & -0.161 & & -0.142 & & -0.165 \\
\hline & & $(0.009)^{* *}$ & & $(0.012)^{* *}$ & & $(0.014)^{* *}$ \\
\hline \multirow[t]{2}{*}{ Single } & & -0.013 & & -0.120 & & 0.030 \\
\hline & & $(0.004)^{* *}$ & & $(0.006)^{* *}$ & & $(0.005)^{* *}$ \\
\hline Stockholm & \multicolumn{2}{|c|}{ Reference Category } & & & & \\
\hline \multirow[t]{2}{*}{\begin{tabular}{|l|} 
Skåne \\
\end{tabular}} & & -0.122 & & -0.122 & & -0.122 \\
\hline & & $(0.004)^{* *}$ & & $(0.005)^{* *}$ & & $(0.005)^{* *}$ \\
\hline \multirow[t]{2}{*}{\begin{tabular}{|l|} 
Västra Götaland \\
\end{tabular}} & & -0.062 & & -0.062 & & -0.064 \\
\hline & & $(0.004)^{* *}$ & & $(0.005)^{* *}$ & & $(0.005) * *$ \\
\hline \multirow[t]{2}{*}{ Other counties } & & -0.070 & & -0.072 & & -0.072 \\
\hline & & $(0.003)^{* *}$ & & $(0.004)^{* *}$ & & $(0.004)^{* *}$ \\
\hline Number of obs. & 311,341 & 250,913 & 130,113 & 130,113 & 120,800 & 120,800 \\
\hline
\end{tabular}

* indicates significance at the 5-\% level, and ** at the 1-\% level. 


\section{Income from work}

An important question is what kind of wage income the unaccompanied minors with employment have. We have related the wage income to different characteristics by estimating wage equations. We have estimated wage equations (with wage income as a dependent variable) for the entire group, as well as for men and women separately. See Table 6 . The income refers to different years. In order to make wage incomes from different years comparable, we have used the consumer price index to give them the same monetary value.

The calculations for the entire group with a wage income show that women have much lower incomes than men (32 per cent lower), given a number of variables such as age, education, length of stay in Sweden, marital status, and country of birth. When we look at the separate estimates for men and women, we can see largely similar results for men and women. The same variables are significant, and the effects are about the same size.

The wage income increases with age (which can be seen as a measure of experience) and education. Those who are studying at the same time have significantly lower incomes (they probably work part-time to a large extent). In particular, the wage income increases with the number of days the people have been registered in Sweden. When we factor in age, we can see that the wage income at a specific age is higher if the person came to Sweden at a young age. Furthermore, it is very clear that residents of Stockholm County have much higher incomes than residents of other counties. In separate calculations for men and women we find a significant difference for men, but not for women (an explanation for this might be that we have few observations). We have also included a variable for changing counties (we have not taken into account which counties the people have moved between), which, perhaps somewhat surprisingly, shows a weak negative effect. ${ }^{9}$ It is not likely that moving to a different county leads to a negative result, but rather that those who move have low incomes both before and after moving. When it comes to country of birth, we have, as in previous calculations, used Afghanistan as a comparison country. Here we can see no significant differences between different countries.

\footnotetext{
${ }^{9}$ We can see a clearly negative effect if we instead include moving to Stockholm as a variable. This can be interpreted to mean that those who move to Stockholm have low incomes and that, although income levels are higher in Stockholm than in other counties, those who move still have low incomes. We will investigate the effect of moving in the future.
} 
Table 6. Factors affecting the wage income of unaccompanied minors. OLS estimates.

\begin{tabular}{|c|c|c|c|}
\hline Variables & All & Male & Female \\
\hline \multirow[t]{2}{*}{ Female } & -0.315 & & \\
\hline & $(0.038)^{* *}$ & & \\
\hline Age 16-18 & \multicolumn{2}{|c|}{ Reference category } & \\
\hline \multirow{2}{*}{ Age 19-21 } & 0.476 & 0.433 & 0.889 \\
\hline & $(0.051)^{* *}$ & $(0.049) * *$ & $(0.244) * *$ \\
\hline \multirow[t]{2}{*}{ Age 22-24 } & 0.607 & 0.592 & 0.905 \\
\hline & $(0.066)^{* *}$ & $(0.065) * *$ & $(0.269)^{* *}$ \\
\hline \multirow[t]{2}{*}{ Age 25-26 } & 0.638 & 0.639 & 0.960 \\
\hline & $(0.091)^{* *}$ & $(0.093) * *$ & $(0.314)^{* *}$ \\
\hline \multirow[t]{2}{*}{ Age $27-30$} & 0.620 & 0.568 & 1.186 \\
\hline & $(0.124)^{* *}$ & $(0.126) * *$ & $(0.421)^{* *}$ \\
\hline \multirow[t]{2}{*}{ Under education } & -0.259 & -0.330 & -0.005 \\
\hline & $(0.028)^{* *}$ & $(0.030) * *$ & $(0.080)$ \\
\hline Compulsory edu $<9$ yrs & \multicolumn{2}{|c|}{ Reference category } & \\
\hline \multirow[t]{2}{*}{ Compulsory edu (9 yrs) } & -0.082 & -0.093 & 0.148 \\
\hline & (0.039)* & (0.038)* & $(0.155)$ \\
\hline \multirow[t]{2}{*}{ High school } & 0.099 & 0.070 & 0.376 \\
\hline & $(0.038)^{* *}$ & $(0.038)$ & $(0.144) * *$ \\
\hline \multirow[t]{2}{*}{ Short tertiary edu } & -0.363 & -0.337 & -0.349 \\
\hline & $(0.086)^{* *}$ & $(0.088) * *$ & $(0.270)$ \\
\hline \multirow[t]{2}{*}{ Long tertiary edu } & 0.100 & 0.089 & 0.283 \\
\hline & (0.095) & $(0.105)$ & $(0.245)$ \\
\hline \multirow[t]{2}{*}{ Missing edu } & -0.113 & -0.086 & -0.111 \\
\hline & $(0.042)^{* *}$ & $(0.042)^{*}$ & $(0.152)$ \\
\hline \multirow[t]{2}{*}{ Days registered in Sweden/100 } & 0.020 & 0.021 & 0.014 \\
\hline & $(0.003)^{* *}$ & $(0.003) * *$ & $(0.008)$ \\
\hline \multirow[t]{2}{*}{ First year } & -0.036 & -0.121 & 0.768 \\
\hline & $(0.122)$ & $(0.119)$ & $(0.506)$ \\
\hline \multirow[t]{2}{*}{ Parents registered in Sweden } & 0.002 & -0.003 & 0.161 \\
\hline & $(0.044)$ & (0.043) & $(0.160)$ \\
\hline \multirow[t]{2}{*}{ Single } & -0.037 & -0.006 & -0.153 \\
\hline & $(0.032)$ & (0.035) & (0.086) \\
\hline \multirow[t]{2}{*}{ Moving across counties } & -0.067 & -0.067 & -0.080 \\
\hline & $(0.030) *$ & $(0.032)^{*}$ & $(0.082)$ \\
\hline Stockholm & Reference & gory & \\
\hline Skåne & -0.146 & -0.162 & 0.007 \\
\hline & $(0.053)^{* *}$ & $(0.052) * *$ & $(0.210)$ \\
\hline Västra Götaland & -0.085 & -0.124 & 0.145 \\
\hline & (0.039)* & $(0.039) * *$ & $(0.140)$ \\
\hline Other counties & -0.166 & -0.178 & -0.110 \\
\hline & $(0.028)^{* *}$ & $(0.029) * *$ & $(0.084)$ \\
\hline Afghanistan & Reference & gory & \\
\hline Irak & 0.035 & 0.018 & -0.101 \\
\hline & (0.034) & $(0.032)$ & $(0.251)$ \\
\hline Somalia & 0.033 & 0.055 & -0.139 \\
\hline & $(0.042)$ & $(0.042)$ & $(0.215)$ \\
\hline Other countries in the M.E. & 0.034 & -0.023 & -0.033 \\
\hline & $(0.071)$ & $(0.076)$ & $(0.263)$ \\
\hline Other countries in Africa & 0.029 & 0.050 & -0.142 \\
\hline & $(0.050)$ & (0.058) & $(0.216)$ \\
\hline Europé & -0.007 & 0.002 & -0.192 \\
\hline & $(0.099)$ & $(0.105)$ & $(0.321)$ \\
\hline Other countries in Asia & 0.082 & 0.084 & -0.119 \\
\hline & $(0.082)$ & $(0.086)$ & $(0.290)$ \\
\hline Constant & 11.174 & 11.221 & 10.520 \\
\hline & $(0.075)^{* *}$ & $(0.076) * *$ & $(0.336)^{* *}$ \\
\hline Number of obs. & 2,893 & 2,350 & 543 \\
\hline
\end{tabular}

* indicates significance at the 5-\% level, and ** at the 1-\% level. 
We have made similar estimations for our comparison group - those who came to Sweden as children from the same countries, but not as unaccompanied minors. This group is much larger, which means that we have obtained significant results to a larger extent. There are a few differences, one of which is that single women have higher incomes than married women (a possible explanation for this are differences in the prevalence of seasonal and part-time work). This is a common finding in the literature for all population groups (Baker and Benjamin, 1997, Duleep and Sanders, 1993). This variable was not significant in the previously presented employment calculations, which suggests that marital status does not affect women's likelihood of being employed, but rather how much they work. However, being single has a negative correlation with income for men. This is also a common result, which can either be explained by the fact that married men tend to work more and thus earn more than unmarried men, or by the fact that men with higher incomes are more likely to get married.

Another result is that individuals who came from countries in Europe (from countries outside the EU/EEA) have higher incomes than those from Afghanistan. All other groups have lower incomes than those who came from Afghanistan. See Table 7. However, the group born in Europe (countries outside the EU/EEA) also includes individuals who did not come as refugees from these countries.

There are significant differences between counties of residence. Residents of Stockholm County have the highest incomes. This applies to both men and women, but even more so to women. The coefficient for internal migration is negative, which may indicate that the positive Stockholm effect cannot be explained by highly capable people moving to Stockholm.

We can see a negative effect in the first year after being entered into the population register; few people worked throughout the year during which they were registered. 
Table 7. Factors affecting the wage income of other children from the same countries who did not arrive unaccompanied. OLS estimates.

\begin{tabular}{|c|c|c|c|}
\hline Variables & All & Male & Female \\
\hline \multirow[t]{2}{*}{ Female } & -0.273 & & \\
\hline & $(0.002)^{* *}$ & & \\
\hline Age 16-18 & \multicolumn{2}{|c|}{ Reference category } & \\
\hline \multirow[t]{2}{*}{ Age 19-21 } & 0.513 & 0.494 & 0.527 \\
\hline & $(0.008)^{* *}$ & $(0.010)^{* *}$ & $(0.012)^{* *}$ \\
\hline \multirow[t]{2}{*}{ Age $22-24$} & 0.807 & 0.830 & 0.772 \\
\hline & $(0.008) * *$ & $(0.010) * *$ & $(0.013)^{* *}$ \\
\hline \multirow[t]{2}{*}{ Age $25-26$} & 0.949 & 0.983 & 0.898 \\
\hline & $(0.008) * *$ & $(0.011)^{* *}$ & $(0.013)^{* *}$ \\
\hline \multirow[t]{2}{*}{ Age $27-30$} & 1.014 & 1.063 & 0.947 \\
\hline & $(0.009)^{* *}$ & $(0.011)^{* *}$ & $(0.013)^{* *}$ \\
\hline \multirow[t]{2}{*}{ Under education } & -0.326 & -0.412 & -0.260 \\
\hline & $(0.003)^{* *}$ & $(0.004)^{* *}$ & $(0.004)^{* *}$ \\
\hline Compulsory edu $<9$ yrs & \multicolumn{2}{|c|}{ Reference category } & \\
\hline \multirow{2}{*}{ Compulsory edu (9 år) } & -0.018 & 0.001 & -0.038 \\
\hline & $(0.008)^{*}$ & (0.009) & $(0.014)^{* *}$ \\
\hline \multirow[t]{2}{*}{ High School } & 0.111 & 0.135 & 0.097 \\
\hline & $(0.008) * *$ & $(0.009) * *$ & $(0.014)^{* *}$ \\
\hline \multirow[t]{2}{*}{ Short tertiary edu } & 0.033 & 0.006 & 0.067 \\
\hline & $(0.009)^{* *}$ & $(0.011)$ & $(0.015)^{* *}$ \\
\hline \multirow[t]{2}{*}{ Long tertiary edu } & 0.292 & 0.239 & 0.356 \\
\hline & $(0.008)^{* *}$ & $(0.010)^{* *}$ & $(0.014)^{* *}$ \\
\hline \multirow[t]{2}{*}{ Missing edu } & 0.054 & 0.106 & 0.023 \\
\hline & $(0.011)^{* *}$ & $(0.013)^{* *}$ & $(0.020)$ \\
\hline \multirow[t]{2}{*}{ Days registered in Sweden/100 } & 0.002 & 0.002 & 0.001 \\
\hline & $(0.000) * *$ & $(0.000)^{* *}$ & $(0.000)^{* *}$ \\
\hline \multirow[t]{2}{*}{ First year } & -0.115 & -0.116 & -0.112 \\
\hline & $(0.004)^{* *}$ & $(0.005)^{* *}$ & $(0.007)^{* *}$ \\
\hline \multirow[t]{2}{*}{ Single } & 0.114 & -0.037 & 0.224 \\
\hline & $(0.003) * *$ & $(0.004)^{* *}$ & $(0.004)^{* *}$ \\
\hline \multirow[t]{2}{*}{ Moving across counties } & -0.009 & -0.023 & -0.004 \\
\hline & $(0.003) * *$ & $(0.004)^{* *}$ & $(0.005)$ \\
\hline Stockholm & \multicolumn{2}{|c|}{ Reference category } & \\
\hline \multirow[t]{2}{*}{ Skåne } & -0.092 & -0.068 & -0.118 \\
\hline & $(0.004)^{* *}$ & $(0.005)^{* *}$ & $(0.006)^{* *}$ \\
\hline Västra Götaland & -0.056 & -0.021 & -0.094 \\
\hline & $(0.003)^{* *}$ & $(0.004)^{* *}$ & $(0.005)^{* *}$ \\
\hline Other counties & -0.101 & -0.068 & -0.138 \\
\hline & $(0.003) * *$ & $(0.004)^{* *}$ & $(0.005)^{* *}$ \\
\hline Afghanistan & Reference & gory & \\
\hline Irak & -0.044 & -0.059 & -0.010 \\
\hline & $(0.009)^{* *}$ & $(0.010)^{* *}$ & $(0.016)$ \\
\hline Somalia & -0.073 & -0.102 & -0.054 \\
\hline & $(0.010) * *$ & $(0.012)^{* *}$ & $(0.018)^{* *}$ \\
\hline Other countries in the M.E. & -0.112 & -0.150 & -0.051 \\
\hline & $(0.008)^{* *}$ & $(0.009) * *$ & $(0.015)^{* *}$ \\
\hline Other countries in Africa & -0.060 & -0.092 & -0.014 \\
\hline & $(0.009)^{* *}$ & $(0.010) * *$ & $(0.016)$ \\
\hline Europé & 0.024 & 0.034 & 0.018 \\
\hline & $(0.008)^{* *}$ & $(0.009)^{* *}$ & (0.015) \\
\hline Other countries in Asia & -0.090 & -0.093 & -0.071 \\
\hline & $(0.009)^{* *}$ & $(0.010)^{* *}$ & $(0.015)^{* *}$ \\
\hline Constant & 11.189 & 11.265 & 10.882 \\
\hline & $(0.014)^{* *}$ & $(0.016) * *$ & $(0.023)^{* *}$ \\
\hline Number of obs. & 404,084 & 206,894 & 197,190 \\
\hline
\end{tabular}

* indicates significance at the 5-\% level, and ** at the 1-\% level. 
The next step is to combine the two groups of children - the unaccompanied ones and those who came with their parents or another legal guardian. See Table 8. Once again, a large negative coefficient value disappears when we control for age. We find that, given the various control variables, unaccompanied minors have higher incomes than other minors from the same countries. This is the case for both men and women; the difference is 11 per cent for men and 8 per cent for women. It is important to note that our data do not include the number of hours worked, so we cannot calculate the hourly wage. Thus, these results may simply reflect the fact that unaccompanied minors work more hours rather than earn more per hour.

With the exception of those who came from Europe (from countries outside the EU/EEA), wage incomes are higher for individuals from Afghanistan than for individuals from other regions. 
Table 8. Factors affecting the wage incomes of unaccompanied and other minors. OLS estimates.

\begin{tabular}{|c|c|c|c|c|c|}
\hline Variables & All (1) & All (2) & All (3) & Male & Female \\
\hline \multirow[t]{2}{*}{ Unaccompanied } & -0.213 & -0.014 & 0.078 & 0.113 & 0.085 \\
\hline & $(0.016) * *$ & $(0.014)$ & $(0.014)^{* *}$ & $(0.014)^{* *}$ & $(0.035)^{*}$ \\
\hline \multirow[t]{2}{*}{ Female } & & -0.285 & -0.274 & & \\
\hline & & $(0.002)^{* *}$ & $(0.002)^{* *}$ & & \\
\hline Age 16-18 & \multicolumn{2}{|c|}{ Reference category } & & & \\
\hline \multirow[t]{2}{*}{ Age 19-21 } & & 0.761 & 0.515 & 0.498 & 0.528 \\
\hline & & $(0.008)^{* *}$ & $(0.008)^{* *}$ & $(0.010)^{* *}$ & $(0.012) * *$ \\
\hline \multirow[t]{2}{*}{ Age $22-24$} & & 1.125 & 0.809 & 0.832 & 0.773 \\
\hline & & $(0.008) * *$ & $(0.008)^{* *}$ & $(0.010)^{* *}$ & $(0.013) * *$ \\
\hline \multirow{2}{*}{ Age 25-26 } & & 1.330 & 0.952 & 0.986 & 0.898 \\
\hline & & $(0.008) * *$ & $(0.008)^{* *}$ & $(0.011)^{* *}$ & $(0.013)^{* *}$ \\
\hline \multirow[t]{2}{*}{ Age 27-30 } & & 1.427 & 1.016 & 1.066 & 0.947 \\
\hline & & $(0.007)^{* *}$ & $(0.008)^{* *}$ & $(0.011)^{* *}$ & $(0.013) * *$ \\
\hline \multirow[t]{2}{*}{ Under education } & & & -0.326 & -0.411 & -0.259 \\
\hline & & & $(0.003) * *$ & $(0.004)^{* *}$ & $(0.004) * *$ \\
\hline Compulsory edu $<9$ yrs & \multicolumn{2}{|c|}{\begin{tabular}{|l|} 
Reference category \\
\end{tabular}} & & & \\
\hline \multirow{2}{*}{ Compulsory edu (9 yrs) } & & & -0.019 & -0.004 & -0.037 \\
\hline & & & $(0.008)^{*}$ & (0.009) & $(0.014)^{* *}$ \\
\hline \multirow[t]{2}{*}{ High school } & & & 0.109 & 0.129 & 0.098 \\
\hline & & & $(0.008) * *$ & $(0.009)^{* *}$ & $(0.014)^{* *}$ \\
\hline \multirow[t]{2}{*}{ Short tertiary edu } & & & 0.030 & -0.001 & 0.068 \\
\hline & & & $(0.009)^{* *}$ & $(0.010)$ & $(0.015) * *$ \\
\hline \multirow[t]{2}{*}{ Long tertiary edu } & & & 0.290 & 0.233 & 0.357 \\
\hline & & & $(0.008)^{* *}$ & $(0.010)^{* *}$ & $(0.014)^{* *}$ \\
\hline \multirow[t]{2}{*}{ Missing edu } & & & 0.041 & 0.089 & 0.015 \\
\hline & & & $(0.011)^{* *}$ & $(0.012)^{* *}$ & (0.019) \\
\hline \multirow{2}{*}{ Days registered in Sweden/100 } & & & 0.002 & 0.002 & 0.001 \\
\hline & & & $(0.000)^{* *}$ & $(0.000)^{* *}$ & $(0.000) * *$ \\
\hline \multirow[t]{2}{*}{ First year } & & & -0.115 & -0.116 & -0.112 \\
\hline & & & $(0.004) * *$ & $(0.005) * *$ & $(0.007)^{* *}$ \\
\hline \multirow[t]{2}{*}{ Single } & & & 0.113 & -0.037 & 0.223 \\
\hline & & & $(0.003)^{* *}$ & $(0.004)^{* *}$ & $(0.004)^{* *}$ \\
\hline Moving across counties & & & -0.009 & -0.023 & -0.004 \\
\hline & & & $(0.003)^{* *}$ & $(0.004)^{* *}$ & $(0.004)$ \\
\hline Stockholm & Reference & gory & & & \\
\hline Skåne & & & -0.092 & -0.069 & -0.118 \\
\hline & & & $(0.004) * *$ & $(0.005) * *$ & $(0.006) * *$ \\
\hline Västra Götaland & & & -0.057 & -0.022 & -0.094 \\
\hline & & & $(0.003) * *$ & $(0.004) * *$ & $(0.005) * *$ \\
\hline Other counties & & & -0.102 & -0.070 & -0.138 \\
\hline & & & $(0.003)^{* *}$ & $(0.004)^{* *}$ & $(0.005) * *$ \\
\hline Afghanistan & Reference & gory & & & \\
\hline Irak & & & -0.037 & -0.049 & -0.009 \\
\hline & & & $(0.008)^{* *}$ & $(0.009)^{* *}$ & $(0.016)$ \\
\hline Somalia & & & -0.063 & -0.089 & -0.051 \\
\hline & & & $(0.010)^{* *}$ & $(0.011)^{* *}$ & $(0.018)^{* *}$ \\
\hline Other countries in the M.E. & & & -0.105 & -0.140 & -0.050 \\
\hline & & & $(0.008) * *$ & $(0.009) * *$ & $(0.015) * *$ \\
\hline Other countries in Africa & & & -0.053 & -0.082 & -0.014 \\
\hline & & & $(0.009)^{* *}$ & $(0.010)^{* *}$ & $(0.016)$ \\
\hline Europé & & & 0.031 & 0.044 & 0.018 \\
\hline & & & $(0.008)^{* *}$ & $(0.009) * *$ & (0.015) \\
\hline Other countries in Asia & & & -0.083 & -0.083 & -0.070 \\
\hline & & & $(0.008) * *$ & $(0.009) * *$ & $(0.015)^{* *}$ \\
\hline Constant & 11.976 & 10.938 & 11.183 & 11.259 & 10.881 \\
\hline & $(0.001) * *$ & $(0.007) * *$ & $(0.013) * *$ & $(0.016) * *$ & $(0.023) * *$ \\
\hline Number of obs. & 406,977 & 406,977 & 406,977 & 209,244 & 197,733 \\
\hline
\end{tabular}

* indicates significance at the 5-\% level, and ** at the 1-\% level. 
In a final step, we compare those who came to Sweden as unaccompanied minors and other people from the same countries with Swedish-born people of the same age with Swedish-born parents. See Table 9.

In the calculation of wage incomes, the major negative coefficient associated with being an unaccompanied minor disappears and becomes insignificant for both men and women in comparison with those born in Sweden when we include all variables. Furthermore, when comparing other minors from these countries to those with a Swedish background, we can see that the negative coefficient for men remains, while women tend to earn slightly more than their counterparts with a Swedish background. It is possible that employed women from these countries are a more positively selected group compared to young employed women with a Swedish background. Another possible reason for this might be that they work more hours, as they have a responsibility to help support family members or relatives here or in their home country. 
Table 9. Wage income among minors - unaccompanied, others from the same countries, Swedish background.

\begin{tabular}{|c|c|c|c|c|c|c|}
\hline Variables & All (1) & All (2) & Male (1) & Male (2) & Female (1) & Female (2) \\
\hline Child+parents born in Sweden & \multicolumn{2}{|c|}{ Reference category } & & & & \\
\hline \multirow[t]{2}{*}{ Unaccompanied } & -0.314 & -0.047 & -0.448 & -0.023 & -0.324 & -0.045 \\
\hline & $(0.025)^{* *}$ & $(0.022)^{*}$ & $(0.025)^{* *}$ & $(0.022)$ & $(0.063)^{* *}$ & $(0.057)$ \\
\hline \multirow{2}{*}{ Accompanied } & -0.027 & -0.034 & -0.064 & -0.080 & 0.010 & 0.018 \\
\hline & $(0.005)^{* *}$ & $(0.004)^{* *}$ & $(0.006)^{* *}$ & $(0.005)^{* *}$ & $(0.007)$ & $(0.007) * *$ \\
\hline \multirow{2}{*}{\begin{tabular}{|l|} 
Female \\
\end{tabular}} & & -0.293 & & & & \\
\hline & & $(0.004)^{* *}$ & & & & \\
\hline Age 16-18 & \multicolumn{2}{|c|}{ Reference category } & & & & \\
\hline \multirow{2}{*}{ Age 19-21 } & & 0.619 & & 0.603 & & 0.618 \\
\hline & & $(0.014)^{* *}$ & & $(0.018)^{* *}$ & & $(0.022)^{* *}$ \\
\hline \multirow[t]{2}{*}{\begin{tabular}{|l|} 
Age $22-24$ \\
\end{tabular}} & & 0.942 & & 0.986 & & 0.868 \\
\hline & & $(0.014)^{* *}$ & & $(0.018)^{* *}$ & & $(0.022)^{* *}$ \\
\hline \multirow[t]{2}{*}{\begin{tabular}{|l|} 
Age $25-26$ \\
\end{tabular}} & & 1.078 & & 1.146 & & 0.974 \\
\hline & & $(0.015) * *$ & & $(0.019)^{* *}$ & & $(0.023) * *$ \\
\hline \multirow[t]{2}{*}{ Age 27-30 } & & 1.164 & & 1.252 & & 1.032 \\
\hline & & $(0.015)^{* *}$ & & $(0.018)^{* *}$ & & $(0.023)^{* *}$ \\
\hline \multirow[t]{2}{*}{ Under education } & & -0.394 & & -0.499 & & -0.316 \\
\hline & & $(0.005)^{* *}$ & & $(0.007)^{* *}$ & & $(0.008)^{* *}$ \\
\hline \multirow[t]{2}{*}{ Compulsory edu (9 år) } & & -0.004 & & 0.065 & & -0.122 \\
\hline & & $(0.019)$ & & $(0.020)^{* *}$ & & $(0.037)^{* *}$ \\
\hline \multirow[t]{2}{*}{ High School } & & 0.160 & & 0.220 & & 0.070 \\
\hline & & $(0.018)^{* *}$ & & $(0.019)^{* *}$ & & $(0.035)^{*}$ \\
\hline \multirow[t]{2}{*}{ Short tertiary edu } & & 0.048 & & 0.073 & & -0.008 \\
\hline & & $(0.019)^{*}$ & & $(0.021)^{* *}$ & & $(0.036)$ \\
\hline \multirow[t]{2}{*}{ Long tertiary edu } & & 0.272 & & 0.249 & & 0.273 \\
\hline & & $(0.018)^{* *}$ & & $(0.020)^{* *}$ & & $(0.035)^{* *}$ \\
\hline \multirow[t]{2}{*}{ Missing edu } & & 0.040 & & 0.133 & & -0.063 \\
\hline & & $(0.026)$ & & $(0.028)^{* *}$ & & $(0.052)$ \\
\hline \multirow[t]{2}{*}{\begin{tabular}{|l|} 
Single \\
\end{tabular}} & & 0.125 & & -0.020 & & 0.224 \\
\hline & & $(0.006)^{* *}$ & & $(0.008)^{* *}$ & & $(0.009) * *$ \\
\hline \begin{tabular}{|l|} 
Stockholm \\
\end{tabular} & \multicolumn{2}{|c|}{ Reference category } & & & & \\
\hline \multirow[t]{2}{*}{ Skåne } & & -0.068 & & -0.031 & & -0.109 \\
\hline & & $(0.007)^{* *}$ & & $(0.008)^{* *}$ & & $(0.011)^{* *}$ \\
\hline \multirow[t]{2}{*}{ Västra Götaland } & & -0.055 & & -0.010 & & -0.106 \\
\hline & & $(0.006)^{* *}$ & & $(0.007)$ & & $(0.010)^{* *}$ \\
\hline \multirow[t]{2}{*}{ Other counties } & & -0.076 & & -0.023 & & -0.136 \\
\hline & & $(0.005)^{* *}$ & & $(0.006)^{* *}$ & & $(0.008)^{* *}$ \\
\hline \multirow[t]{2}{*}{\begin{tabular}{|l|} 
Constant \\
\end{tabular}} & 12.182 & 11.237 & 12.357 & 11.268 & 11.995 & 11.009 \\
\hline & $(0.003)^{* *}$ & $(0.023)^{* *}$ & $(0.004)^{* *}$ & $(0.027)^{* *}$ & $(0.004)^{* *}$ & $(0.042)^{* *}$ \\
\hline Number of obs. & 120,231 & 120,231 & 62,548 & 62,548 & 57,683 & 57,683 \\
\hline
\end{tabular}

* indicates significance at the 5-\% level, and ** at the 1-\% level. 


\section{Conclusions}

We have found that the young people who arrived as unaccompanied minors are more often employed and tend to have higher wage incomes than others from the same countries who arrive with their parents or another legal guardian, given various characteristics such as age and length of stay in Sweden. The reason for this might be that they are a positively selected group; it is possible that the rules and regulations that apply to this group help them establish themselves in the Swedish labour market, or it may be that this group - since they lack parental support - work instead of pursuing an education and that they, for the same reason, work many hours. There is good reason to attempt to find the explanation for this difference.

Regarding the likelihood of employment the results are driven by men. We cannot find significant differences in the likelihood of employment between unaccompanied refugee females versus accompanied refugee females after controlling for observable characteristics. When we compare these two groups of females with their Swedish-born counterparts who have Swedish-born parents, we find that both groups are less likely to be employed, where the unaccompanied refugee females have a larger negative coefficient than that of accompanied refugee females. However, the results point in the opposite direction in the income estimations, where no significant differences are found between unaccompanied refugee females and Swedish females, while a significant positive result is found for accompanied refugee females. These results show that, although refugee females are less likely to be employed, once they are employed they tend to earn as much as or more than their Swedish counterparts, which indicates a positive selection of this group that ends up being employed or working more hours than their Swedish counterparts.

In the case of men, the results clearly show that unaccompanied refugee males are more likely to work compared to accompanied refugee males after controlling for their observable characteristics. However, this is not the case when they are compared to their Swedish counterparts. They are also more likely to earn more compared to their accompanied counterparts, and the results are insignificant compared to their Swedish born counterparts. 
In the list below we will summarise some of our main results regarding the unaccompanied minors’ establishment in the labour market.

1. The unaccompanied minors and others from the same countries are less likely to be employed compared to Swedish-born individuals of the same age with Swedish-born parents.

2. The difference is greater among girls: the employment rate among girls who arrived to Sweden as unaccompanied minors is much lower than among boys.

3. The amount of time passed since the arriving minors were registered in Sweden has a positive effect on their employment.

4. Given the amount of time they have been registered in Sweden, those who arrived as unaccompanied minors are more likely to be employed than those who arrived with their parents (or were later reunited with their parents in Sweden).

5. Residents of Stockholm County are more likely to be employed than those living in other parts of the country.

6. The largest group of unaccompanied minors, those from Afghanistan, are doing relatively well compared to most other groups of unaccompanied minors.

7. Wage incomes increase with age and time spent in Sweden. They are higher for unaccompanied boys in Stockholm than in other counties.

8. Wage incomes are higher for unaccompanied minors compared to others from the same countries when we include all other variables.

9. Compared to Swedish-born individuals with Swedish-born parents, the wage incomes are nearly as high when we account for all other known characteristics. 
References

Ager, A. and Strang, A. (2008) “Understanding Integration: A Conceptual Framework”, Journal of Refugee Studies, 21(2): 166-191.

Alden, L. and Hammarstedt, M. (2014) "Integration of immigrants on the Swedish labor market: recent trends and explanations”, Linnaeus University, Labor Market and Discrimination Studies, Report No. 2014:9.

Baker, M. and Benjamin, D. (1997) “The role of the family in immigrants' labor-market activity: an evaluation of alternative explanations”, American Economic Review, 87(4): $705-727$.

Convention on the Rights of the Child, "Treatment of unaccompanied and separated children outside their country of origin”, CRC/GC/2005/6, United Nations.

Çelikaksoy, A. and Wadensjö, E. (2015a), “Ensamkommande barn i Sverige”, SULCIS Rapport 2015:1.

Çelikaksoy, A. and Wadensjö, E. (2015b), ”Unaccompanied minors and separated refugee children in Sweden: An outlook on demography, education, and employment”, IZA Discussion Paper 8963.

Duleep, H. O. and Sanders, S. (1993) “The decision to work by married immigrant women”, Industrial and Labor Relations Review, 46(4): 677-690.

Eide, K. (2000), ”Barn i bevegelse. Om oppvekst og levekår for enslige mindreårigeflyktninger”, Porsgrunn: Høgskolen i Telemark, Avdeling for helse- og socialfag.

European Commission (2012) "Shaping a common approach on unaccompanied minors”, MEMO/12/716, Brussels.

Hessle, M. (2009) “Ensamkommande men inte ensamma: Tioårsuppföljning av ensamkommande asylsökande flyktingsbarns livsvillkor och erfarenheter som unga vuxna i Sverige”, PhD Thesis, Department of Education, Stockholm University. 
Migrationsverket (2015), ”Aktuellt om ensamkommande barn och ungdomar”, Mars, Rapport.

Neuman, E. (2015), ”Culture, Assimilation, and Gender Gaps in Labour Market Outcomes”, in E. Neuman, Essays on Segregation, Gender Economics and SelfEmployment, Doctoral dissertation, Department of Economics and Statistics, Linnaeus University, Växjö.

UNHCR (2014), ”Unaccompanied and separated asylum-seeking and refugee children turning eighteen: What to celebrate?”, UNHCR/Council of Europe Report March 2014, Strasbourg. 


\section{Appendix tables}

Table A1. Factors affecting the employment rate of unaccompanied minors from Afghanistan. Probit estimations, marginal effects.

\begin{tabular}{|c|c|c|c|}
\hline Variables & Alla & Män & Kvinnor \\
\hline \multirow[t]{2}{*}{ Female } & -0.023 & & \\
\hline & $(0.004)^{* *}$ & & \\
\hline Age 16-18 & \multicolumn{2}{|c|}{ Reference group } & \\
\hline \multirow[t]{2}{*}{ Age 19-21 } & 0.020 & 0.020 & 0.137 \\
\hline & $(0.006)^{* *}$ & $(0.007) * *$ & $(0.089)$ \\
\hline \multirow[t]{2}{*}{ Age 22-24 } & 0.018 & 0.019 & 0.525 \\
\hline & $(0.014)$ & $(0.015)$ & $(0.436)$ \\
\hline \multirow[t]{2}{*}{ Age 25-26 } & -0.019 & -0.020 & \\
\hline & $(0.007)^{* *}$ & $(0.008)^{* *}$ & \\
\hline \multirow[t]{2}{*}{ Age $27-30$} & -0.021 & -0.017 & \\
\hline & $(0.010)^{*}$ & $(0.018)$ & \\
\hline \multirow[t]{2}{*}{ Days registered in Sweden/100 } & 0.006 & 0.006 & 0.011 \\
\hline & $(0.001)^{* *}$ & $(0.001)^{* *}$ & $(0.007)$ \\
\hline \multirow[t]{2}{*}{ First year } & -0.031 & -0.030 & \\
\hline & $(0.005)^{* *}$ & $(0.006)^{* *}$ & \\
\hline \multirow{2}{*}{ Parents registered in Sweden } & -0.011 & -0.007 & \\
\hline & $(0.005)^{*}$ & $(0.006)$ & \\
\hline \multirow[t]{2}{*}{ Under education } & -0.044 & -0.044 & -0.139 \\
\hline & $(0.008)^{* *}$ & $(0.008)^{* *}$ & $(0.102)$ \\
\hline Compulsory edu $<9$ yrs & \multicolumn{2}{|c|}{ Reference group } & \\
\hline \multirow[t]{2}{*}{ Compulsory edu (9 yrs) } & -0.007 & -0.007 & -0.086 \\
\hline & $(0.005)$ & $(0.005)$ & $(0.040)^{*}$ \\
\hline \multirow[t]{2}{*}{ High school } & 0.017 & 0.022 & -0.079 \\
\hline & $(0.010)$ & $(0.011)^{*}$ & $(0.035)^{*}$ \\
\hline \multirow[t]{2}{*}{ Short tertiary edu } & 0.015 & 0.022 & \\
\hline & $(0.025)$ & $(0.030)$ & \\
\hline \multirow{2}{*}{ Long tertiary edu } & 0.033 & 0.040 & \\
\hline & $(0.045)$ & $(0.052)$ & \\
\hline \multirow[t]{2}{*}{ Missing edu } & -0.008 & -0.008 & -0.090 \\
\hline & $(0.006)$ & $(0.006)$ & $(0.071)$ \\
\hline \multirow[t]{2}{*}{ Single } & -0.013 & -0.021 & 0.107 \\
\hline & $(0.009)$ & $(0.011)$ & $(0.052)^{*}$ \\
\hline \multirow[t]{2}{*}{ Moving across counties } & -0.002 & -0.004 & -0.041 \\
\hline & $(0.005)$ & $(0.005)$ & $(0.054)$ \\
\hline Stockholm & \multicolumn{2}{|c|}{ Reference group } & \\
\hline \multirow[t]{2}{*}{ Skåne } & -0.032 & -0.032 & \\
\hline & $(0.003)^{* *}$ & $(0.003) * *$ & \\
\hline \multirow[t]{2}{*}{ Västra Götaland } & -0.025 & -0.025 & -0.082 \\
\hline & $(0.003)^{* *}$ & $(0.003) * *$ & $(0.044)$ \\
\hline \multirow[t]{2}{*}{ Other counties } & -0.034 & -0.036 & 0.014 \\
\hline & $(0.006)^{* *}$ & $(0.006)^{* *}$ & $(0.073)$ \\
\hline Number of obs. & 8,752 & 8,437 & 117,000 \\
\hline
\end{tabular}

* indicates significance at the 5-\% level, and ** at the 1-\% level. 
Table A2. Factors affecting the employment rate among unaccompanied minors from Somalia. Probit estimations, marginal effects.

\begin{tabular}{|c|c|c|c|}
\hline Variables & Alla & Män & Kvinnor \\
\hline \multirow[t]{2}{*}{ Female } & -0.022 & & \\
\hline & $(0.004)^{* *}$ & & \\
\hline Age 16-18 & \multicolumn{2}{|c|}{ Reference group } & \\
\hline \multirow[t]{2}{*}{ Age 19-21 } & 0.050 & 0.047 & 0.092 \\
\hline & $(0.009)^{* *}$ & $(0.012)^{* *}$ & $(0.017)^{* *}$ \\
\hline \multirow[t]{2}{*}{ Age $22-24$} & 0.123 & 0.110 & 0.225 \\
\hline & $(0.030)^{* *}$ & $(0.038) * *$ & $(0.063)^{* *}$ \\
\hline \multirow[t]{2}{*}{ Age 25-26 } & 0.103 & 0.076 & 0.197 \\
\hline & $(0.044)^{*}$ & $(0.053)$ & $(0.095)^{*}$ \\
\hline \multirow[t]{2}{*}{ Age $27-30$} & 0.013 & -0.019 & 0.083 \\
\hline & $(0.030)$ & $(0.024)$ & $(0.092)$ \\
\hline \multirow[t]{2}{*}{ Days registered in Sweden/100 } & 0.003 & 0.004 & 0.003 \\
\hline & $(0.000)^{* *}$ & $(0.001)^{* *}$ & $(0.001)^{* *}$ \\
\hline \multirow[t]{2}{*}{ First year } & -0.028 & -0.038 & \\
\hline & $(0.007)^{* *}$ & $(0.010)^{* *}$ & \\
\hline \multirow[t]{2}{*}{ Parents registered in Sweden } & 0.001 & 0.026 & -0.026 \\
\hline & $(0.007)$ & $(0.016)$ & $(0.008) * *$ \\
\hline \multirow[t]{2}{*}{ Under education } & -0.017 & -0.030 & -0.006 \\
\hline & $(0.006)^{* *}$ & $(0.010) * *$ & $(0.008)$ \\
\hline Compulsory edu $<9$ yrs & \multicolumn{2}{|c|}{ Reference group } & \\
\hline \multirow[t]{2}{*}{ Compulsory edu (9 yrs) } & -0.005 & -0.009 & -0.001 \\
\hline & $(0.006)$ & $(0.009)$ & $(0.011)$ \\
\hline \multirow[t]{2}{*}{ High school } & 0.064 & 0.070 & 0.080 \\
\hline & $(0.016)^{* *}$ & $(0.022)^{* *}$ & $(0.031)^{* *}$ \\
\hline \multirow[t]{2}{*}{ Short tertiary edu } & 0.038 & 0.086 & \\
\hline & $(0.028)$ & $(0.050)$ & \\
\hline \multirow[t]{2}{*}{ Long tertiary edu } & 0.044 & 0.145 & -0.022 \\
\hline & $(0.037)$ & $(0.094)$ & $(0.014)$ \\
\hline \multirow[t]{2}{*}{ Missing edu } & -0.004 & -0.002 & -0.012 \\
\hline & $(0.006)$ & $(0.010)$ & $(0.011)$ \\
\hline \multirow[t]{2}{*}{ Single } & -0.007 & -0.016 & -0.001 \\
\hline & $(0.005)$ & $(0.010)$ & $(0.008)$ \\
\hline \multirow[t]{2}{*}{ Moving across counties } & -0.008 & -0.014 & -0.006 \\
\hline & $(0.004)^{*}$ & $(0.006)^{*}$ & $(0.007)$ \\
\hline Stockholm & \multicolumn{2}{|c|}{ Reference group } & \\
\hline \multirow[t]{2}{*}{ Skåne } & 0.002 & -0.004 & 0.009 \\
\hline & $(0.009)$ & $(0.012)$ & $(0.020)$ \\
\hline \multirow[t]{2}{*}{ Västra Götaland } & -0.017 & -0.023 & -0.022 \\
\hline & $(0.004)^{* *}$ & $(0.006)^{* *}$ & $(0.008)^{* *}$ \\
\hline \multirow[t]{2}{*}{ Other counties } & -0.023 & -0.040 & -0.018 \\
\hline & $(0.005)^{* *}$ & $(0.009)^{* *}$ & $(0.008)^{*}$ \\
\hline Number of obs. & 5,820 & 3,241 & 2,032 \\
\hline
\end{tabular}

* indicates significance at the 5-\% level, and ** at the 1-\% level. 
Table A3. Factors affecting the employment rate among unaccompanied minors from Iraq. Probit estimations, marginal effects.

\begin{tabular}{|c|c|c|c|}
\hline Variables & All & Male & Female \\
\hline \multirow[t]{2}{*}{ Female } & -0.127 & & \\
\hline & $(0.009) * *$ & & \\
\hline Age 16-18 & \multicolumn{2}{|c|}{ Reference group } & \\
\hline \multirow{2}{*}{ Age 19-21 } & 0.120 & 0.130 & 0.098 \\
\hline & $(0.017)^{* *}$ & $(0.019)^{* *}$ & $(0.050)$ \\
\hline \multirow[t]{2}{*}{ Age 22-24 } & 0.217 & 0.250 & 0.106 \\
\hline & $(0.035) * *$ & $(0.039) * *$ & $(0.096)$ \\
\hline \multirow[t]{2}{*}{\begin{tabular}{|l|} 
Age $25-26$ \\
\end{tabular}} & 0.214 & 0.289 & 0.002 \\
\hline & $(0.062) * *$ & $(0.071)^{* *}$ & $(0.038)$ \\
\hline \multirow[t]{2}{*}{ Age 27-30 } & 0.140 & 0.227 & \\
\hline & $(0.083)$ & $(0.100)^{*}$ & \\
\hline \multirow[t]{2}{*}{ Days registered in Sweden/100 } & 0.006 & 0.005 & 0.004 \\
\hline & $(0.001)^{* *}$ & $(0.001)^{* *}$ & $(0.002)^{*}$ \\
\hline \multirow[t]{2}{*}{\begin{tabular}{|l} 
First year \\
\end{tabular}} & -0.111 & -0.152 & 0.280 \\
\hline & $(0.016)^{* *}$ & $(0.015)^{* *}$ & $(0.171)$ \\
\hline \multirow[t]{2}{*}{ Parents registered in Sweden } & -0.034 & -0.030 & -0.022 \\
\hline & $(0.013)^{* *}$ & $(0.015)^{*}$ & $(0.012)$ \\
\hline \multirow[t]{2}{*}{ Under education } & -0.113 & -0.131 & -0.012 \\
\hline & $(0.012)^{* *}$ & $(0.013)^{* *}$ & $(0.011)$ \\
\hline Compulsory edu $<9$ yrs & \multicolumn{2}{|c|}{ Reference group } & \\
\hline \multirow[t]{2}{*}{ Compulsory edu (9 yrs) } & 0.010 & 0.022 & -0.016 \\
\hline & $(0.014)$ & $(0.016)$ & $(0.012)$ \\
\hline \multirow[t]{2}{*}{ High school } & 0.049 & 0.053 & 0.013 \\
\hline & $(0.018)^{* *}$ & $(0.020)^{* *}$ & $(0.020)$ \\
\hline \multirow[t]{2}{*}{ Short tertiary edu } & -0.017 & 0.009 & \\
\hline & $(0.045)$ & $(0.059)$ & \\
\hline \multicolumn{4}{|l|}{ Long tertiary edu } \\
\hline \multirow[t]{2}{*}{ Missing edu } & -0.011 & -0.010 & 0.002 \\
\hline & $(0.014)$ & $(0.016)$ & $(0.015)$ \\
\hline \multirow[t]{2}{*}{ Single } & -0.023 & -0.023 & -0.008 \\
\hline & $(0.016)$ & $(0.019)$ & $(0.011)$ \\
\hline \multirow[t]{2}{*}{ Moving across counties } & -0.026 & -0.031 & -0.002 \\
\hline & $(0.011)^{*}$ & $(0.013)^{*}$ & $(0.010)$ \\
\hline Stockholm & \multicolumn{2}{|c|}{ Reference group } & \\
\hline \multirow[t]{2}{*}{\begin{tabular}{|l|} 
Skåne \\
\end{tabular}} & -0.108 & -0.119 & -0.025 \\
\hline & $(0.009)^{* *}$ & $(0.011)^{* *}$ & $(0.012)^{*}$ \\
\hline \multirow[t]{2}{*}{ Västra Götaland } & -0.050 & -0.061 & -0.010 \\
\hline & $(0.012)^{* *}$ & $(0.013)^{* *}$ & $(0.010)$ \\
\hline \multirow[t]{2}{*}{ Other counties } & -0.086 & -0.102 & 0.003 \\
\hline & $(0.010)^{* *}$ & $(0.012)^{* *}$ & $(0.010)$ \\
\hline Number of obs. & 5,488 & 4,837 & 641 \\
\hline
\end{tabular}

* indicates significance at the 5-\% level, and ** at the 1-\% level. 
Table A4. Factors affecting the employment rate among unaccompanied minors from Other African countries. Probit estimations, marginal effects.

\begin{tabular}{|c|c|c|c|}
\hline Variables & All & Male & Female \\
\hline \multirow[t]{2}{*}{ Female } & -0.017 & & \\
\hline & $(0.031)$ & & \\
\hline Age 16-18 & \multicolumn{2}{|c|}{ Reference group } & \\
\hline \multirow[t]{2}{*}{ Age 19-21 } & 0.354 & 0.310 & 0.407 \\
\hline & $(0.075)^{* *}$ & $(0.093)^{* *}$ & $(0.122)^{* *}$ \\
\hline \multirow[t]{2}{*}{ Age 22-24 } & 0.621 & 0.706 & 0.552 \\
\hline & $(0.099)^{* *}$ & $(0.121)^{* *}$ & $(0.162) * *$ \\
\hline \multirow[t]{2}{*}{ Age 25-26 } & 0.714 & 0.716 & 0.694 \\
\hline & $(0.098)^{* *}$ & $(0.143)^{* *}$ & $(0.152)^{* *}$ \\
\hline \multirow[t]{2}{*}{ Age $27-30$} & 0.767 & 0.826 & 0.651 \\
\hline & $(0.075)^{* *}$ & $(0.067)^{* *}$ & $(0.227)^{* *}$ \\
\hline \multirow[t]{2}{*}{ Days registered in Sweden/100 } & 0.001 & 0.002 & 0.006 \\
\hline & $(0.003)$ & $(0.004)$ & $(0.005)$ \\
\hline \multicolumn{4}{|l|}{ First year } \\
\hline \multirow[t]{2}{*}{ Parents registered in Sweden } & -0.103 & -0.081 & \\
\hline & $(0.067)$ & $(0.075)$ & \\
\hline \multirow[t]{2}{*}{ Under education } & -0.079 & -0.132 & -0.021 \\
\hline & $(0.038)^{*}$ & $(0.064)^{*}$ & $(0.050)$ \\
\hline Compulsory edu $<9$ yrs & \multicolumn{2}{|c|}{ Reference group } & \\
\hline \multirow[t]{2}{*}{ Compulsory edu (9 yrs) } & -0.209 & -0.152 & -0.256 \\
\hline & $(0.035)^{* *}$ & $(0.064)^{*}$ & $(0.043) * *$ \\
\hline \multirow[t]{2}{*}{ High school } & -0.059 & -0.138 & -0.012 \\
\hline & $(0.056)$ & $(0.072)$ & $(0.081)$ \\
\hline \multirow[t]{2}{*}{ Short tertiary edu } & -0.080 & -0.098 & -0.099 \\
\hline & $(0.059)$ & $(0.072)$ & $(0.085)$ \\
\hline \multirow[t]{2}{*}{ Long tertiary edu } & -0.108 & -0.160 & -0.080 \\
\hline & $(0.053)^{*}$ & $(0.035) * *$ & $(0.098)$ \\
\hline \multirow[t]{2}{*}{ Missing edu } & -0.116 & -0.083 & -0.144 \\
\hline & $(0.051)^{*}$ & $(0.081)$ & $(0.068)^{*}$ \\
\hline \multirow[t]{2}{*}{ Single } & -0.123 & -0.308 & -0.030 \\
\hline & $(0.057)^{*}$ & $(0.130)^{*}$ & $(0.065)$ \\
\hline \multirow[t]{2}{*}{ Moving across counties } & 0.113 & 0.081 & 0.174 \\
\hline & $(0.035)^{* *}$ & $(0.055)$ & $(0.050)^{* *}$ \\
\hline Stockholm & \multicolumn{2}{|c|}{ Reference group } & \\
\hline \multirow[t]{2}{*}{ Skåne } & -0.142 & -0.107 & -0.184 \\
\hline & $(0.038)^{* *}$ & $(0.070)$ & $(0.044)^{* *}$ \\
\hline \multirow[t]{2}{*}{ Västra Götaland } & -0.100 & -0.150 & -0.012 \\
\hline & $(0.038)^{* *}$ & $(0.041)^{* *}$ & $(0.113)$ \\
\hline \multirow[t]{2}{*}{ Other counties } & -0.018 & -0.131 & 0.052 \\
\hline & $(0.033)$ & $(0.056)^{*}$ & $(0.045)$ \\
\hline Number of obs. & 873 & 399 & 467 \\
\hline
\end{tabular}

* indicates significance at the 5-\% level, and ** at the 1-\% level. 